\title{
Challenges and Issues of Female Primary Education: A Case Study of Rajanpur, Pakistan
}

\author{
Zahid Zulfiqar \\ Visiting Lecturer \\ Department of Sociology \\ Bahauddin Zakariya UniversityMultan \\ ranazahidzulfiqar@gmail.com \\ Kamran Ishfaq \\ Associate Professor \& Chairman \\ Department of Sociology \\ Bahauddin Zakariya University Multan \\ dr.kamran@bzu.edu.pk
}

Sajid Pervez

Personal Secretary

The Women University Multan

mahrsajid@gmail.com

\begin{abstract}
The study attempted to examine the socio-cultural factors which create problems in female primary education; to determine the role of families/parents in female primary education and to examine the lack of school facilities that creates hindrance in the school enrolment of the children. The study population of the study was all parents whose children were primary school age by using the interview schedule. The researcher used the stratified simple random sampling and selected the 300 respondents for the stu dy. The researcher used the SPSS software and did the descriptive and inferential statistical analysis. The findings of the study show that majority 155 (51.7) percent of the respondents were une ducated; majority 85(23.3) percent of the respondents whose monthly income was <6000; majority 95 (31.7) percent of the respondents were laborers; culture is significantly and positively correlated with parental and school facilities with p-values .011 and .000 respectively; furthermore, the parental attitude was significantly and positively correlated with school facilities with p-value.000. The results of ANOVA showed that the levels of cultural, parental, and school facilities among different academic qualifications of the
\end{abstract}

(C) 2021 The Authors, Published by The Women University Multan. This is an Open Access Article under the Creative Common Attribution NonCommercial 4.0
Date of Acceptance: 01 December 2021 Available Online: 15 December 2021 
household. The findings show that there is a significant difference in the levels of cultural, parental, and school facilities among different academic qualifications of the household with $p$-values $.000, .000$, and .000 respectively. The findings showed that there was a significant difference in the levels of cultural, parental, and school facilities among different monthly income levels of the household with p-values .000; .000, and .000 respectively. The study recommended that government may have to pay attention in the studied area; construct new schools, give scholarships to needy students and start awareness seminars at the local level.

Keywords: Socio-cultural, Primary Education, School Facilities

\section{Introduction}

Education is the fundamental right of every child without any distinction of caste, color, creed, or any other identity. It is a bitter reality that millions of children are out of school due to their identity. It is evident that sex (female) is one of these identifications that played a vital role in the exclusion of the child. It is reported that globally there were 34.3 million girls schoolgoing age children were excluded from basic education in 2016; 5.6 percent of girls of school-going age were out of school in South Asia. Furthermore, it was also mentioned that 10 percent of girls were out of school at the world level among them 22.9 percent were in lower-income countries; 10.7 percent girls were out of school in Lower-middle- income countries; 4.2 percent females were out of school in upper-middle-income countries; 3.1 percent females were out of school in high-income countries (United Nations Educational, Scientific, and Cultural Organization [UNESCO], institute for statistics, 2018).

According to the statistics presented by the World Bank (2018) that 4,901,479 children were excluded from primary education in Pakistan of which 28.603 percent of students were girls. The Millennium Development Goal (3) emphasized gender equity and women's empowerment. Its main focus is an inclusive mechanism for the girls' primary and secondary level schooling and eliminating disparities and disparities in 2015 (World Bank, 2009). World Bank (2018) highlighted that globally approximately 
60642327 children were excluded from primary schooling in 2016 of which 9.766 percent were females.

Pakistan totally failed in achieving the Millennium Development Goals 2015 (MDGs) to enroll every child in the school without discrimination. There are numerous factors in the failure of achieving MDGs such as low socio-economic parental status (Bass, 2004; Sattar et al., 2012); the poverty compels the parents for child labor instead of providing them education (Donnell, 2005; Gunnarsson, 2006); Wall (2006) highlighted that poor family discourage the formal education for girls and avail the opportunity of unpaid girls' work at home.

Patriarchal structure (Herz and Sperling 2004); gendered attitude of the parents (Chaudhry, 2007); non-availability of basic school facilities such as pure drinking water, latrines, buildings (Herz \& Sperling, 2004); low educational budget (World Bank, 2001; Shah, 2003 ) and furthermore attachment with the traditions, patriarchal structure, and lack of educational facilities and consistency of cast based occupation also played an important role in child labor (Huisman \& Smits, 2009; Kurosaki et al., 2006; Mukherjee \& Das, 2008).

There is a liaison between education, poverty, and gender inequality. The prior studies indicated that household poverty forced parents towards a gendered attitudes (De Silva, 2008). Moreover, children from rural areas were more excluded from basic education than urban areas in South Punjab, Pakistan (Chaudhry \& Rahman, 2009). Gender inequality is a hindrance in the alleviation of poverty and education of females supports poverty alleviation.

Pakistan is a patriarchal society in which parents give priority to the sons over daughters (Miller 2001). The society usually expects and assigns the duties of reproduction, management of the household, raising children, cleaning and making food. If any women want to work, she has to do dual labor. Pakistan is agriculture in which the majority of the girls belongs to rural areas are doing unpaid labor by specifying their education (Noshab, 2006; Latif, 2009). 
The National Plan of Action 2001-2010 (Ministry of Education 2001) mentioned that the net enrollment at primary level is around 12 million (sixty-six percent of the total population), of which 7.6 million are boys $(82$ percent of the total boy population 5-10 y ears old) and 4.8 million were girls (55 percent of the total girl population 5-10). According to the Education Census (Federal Bureau of Statistics and Academy of Educational Planning and Management 2005), girls' enrollment falls from 1,879,612 in grade 1 to $1,003,237$ in grade 5, a drop of almost fifty percent;201,753 in grade 12 , a drop of almost ninety percent in enrollment. Similarly for boys, enrollment falls from 2,473,929 in grade 1 to $1,412,646$ in grade 5, a drop of almost forty-two percent; 200,945 in grade 12 , a drop of almost eighty percent.

Farah (2007) identified that girls' dropout rates were higher than boys in both rural and urban areas. The major causes behind low enrollment was longer school distance of school and home; shortage of school facilities; shortage of female teachers; household poverty; gendered parental attitude.

Latif (2009) highlighted that since Pakistan's independence, the government has made continuous efforts to provide free, universal, basic education to its citizens. This is evidenced by educational plans, policies, and five-year education sector reforms, including partnerships with international agencies and developed countries. However, these efforts have not yielded any gains for the citizens. Pakistan has a literacy rate of 49.9 percent, one of the lowest in South Asia and the rest of the world. Pakistan's male and female literacy rates are 61.7 percent and 35.2 percent. The female literacy rate drops to 25 percent in rural areas, and girls' school enrollment of fifty-five percent drops to twenty percent from Grade 1 to 6. For the purposes of these statistics, a literate person is defined by Pakistan's Ministry of Education as one who can read a newspaper and write a simple letter in any language. Pakistan's population of 167 million is sixty-five percent rural and thirty-five percent urban, with citizens facing multiple interlinked issues affecting their quality of life, such as illiteracy, poverty, and the lack of basic necessities (shelter, gas, water, and electricity). In addition, a culture of feudalism and patriarchy creates structures of power and 
control that deprive citizens of their rights, including that of education (Farah 2007; Latif, 2009). Studies have been conducted on education in Pakistan, but they have been limited in scope in terms of girls' education. This article addresses the gap in female literacy scholarship. Its purpose is to critically analyze the state of girls' education in Pakistan in terms of three factors: the reasons for low literacy and school enrollment rates, gender biases in curriculum and textbooks, and cultural norms. Based on this analysis, the article concludes with measures to increase school enrollment and literacy rates for girls and women.

Gender is a construction of masculine or feminine traits that are based on the socio-cultural context of the society in which society socialized its members with the help of different agencies of socialization (family, education, peer group, religion, mass media, politics, economic spheres of life, etc.). These agencies are assigned the different statuses and roles of both sexes. The children learned from their culture and daily routine experiences how they should have to behave as a girl or a boy (Yelland, 1998). This gendered socialization led towards inequality in every aspect of society. It was mentioned by Lewis and Lockheed (2007) that seventy percent of girls were excluded from basic education in third-world countries due to their socio-economic, ethnic, tribal, lingual, and rural backgrounds. According to (Colclough et al., 2003 and Chege \& Sifuna, 2006) girls were facing more gender inequality in education than boys especially in poor socioeconomic background households and racial minorities. It was evident by the report of UNESCO (2010) that the children who were at risk of enrolment in the schools were from low economic status, ethnic background and among the majority were females. It was explored by Klasen (2002) that female lower education negatively impacted the economic progress of the society. Gender inequality created hindrances in economic growth (Dollar \& Kraay, 2000) and affected education, increased fertility; reduced economic advancement (Galor \& Weil 1996; Lagerlof, 1999). It was investigated that gender equality increased female education and improved economic development in the developed countries whereas it was totally opposite in the developing countries female education and economic growth were affected due to the gender inequality (Dollar \& Gatti, 1999). The sex of the hou sehold head 
did matter in deciding the inclusion or exclusion of the primary school-age children. The study was conducted by Shahidul (2013) in Bangladesh to find out the decision-making authority of the female and its effect on the exclusion of children in education. It was found that the involvement of females in the decision-making had positively decreased the educational exclusion.

According to Knowles et al. (2002) in developing countries, female education reduced fertility, infant mortality, and increased children's education. Gender Inequalities in education existed in almost all the poor countries. There had been a considerable increase in gender inequality in education in low-income countries over the last three decades (World Bank, 2001). Gender inequality was then considered as an essential concept for the analysis and alleviation of poverty because of its adverse impacts on a number of valuable development goals. Girls' access to education was influenced by poverty in various ways. Recent evidence from West Africa suggested that Poverty had many contributions to gender inequality in access to education (Okoijie, 1998; Okoijie, 2002; Appleton, 1996; Atolagbe, 1999).

\section{School Facilities}

It was mentioned that the main issue in the exclusion from the primary school of the South Punjab children was due to the poor facilities of schools. The schools were missing the basic facilities like pure drinking water, electricity, boundary wall, fans, light, blackboards, classes, and even teachers are also missing from the schools (ASER, 2015).

\section{Research Methodology}

The Quantitative research design was used for this research. The study population of the study was all parents whose children were lies between 5-9 years old by using the interview schedule. The researcher used the stratified simple random sampling and selected the 300 respondents for the study. The sample size of this study was 300 parents. 
Results and Discussion

Table 1: Descriptive Statistics of Overall Concerned Variables under Study

\begin{tabular}{|c|c|c|c|c|}
\hline $\begin{array}{l}\text { Individual } \\
\text { factors }\end{array}$ & Category/Minimum & $\begin{array}{l}\text { Freque } \\
\text { ncy } \\
(\%) / \\
\text { Maxim } \\
\text { um } \\
\end{array}$ & $\begin{array}{l}\text { Mea } \\
\text { n }\end{array}$ & SD \\
\hline \multirow{4}{*}{$\begin{array}{l}\text { Academic } \\
\text { Qualification }\end{array}$} & Uneducated & $\begin{array}{l}155 \\
(51.7)\end{array}$ & --- & --- \\
\hline & Primary & $\begin{array}{l}63 \\
(21.0)\end{array}$ & --- & --- \\
\hline & Secondary & $\begin{array}{l}41 \\
(13.7)\end{array}$ & & \\
\hline & $\begin{array}{l}\text { Higher secondary and } \\
\text { above }\end{array}$ & $\begin{array}{l}41 \\
(13.7)\end{array}$ & & \\
\hline \multirow{5}{*}{ Monthly Income } & $<6000$ & $\begin{array}{l}85 \\
(23.3)\end{array}$ & --- & --- \\
\hline & $6001-11000$ & $\begin{array}{l}62 \\
(20.7)\end{array}$ & & \\
\hline & $11001-16000$ & $\begin{array}{l}76 \\
(25.3)\end{array}$ & & \\
\hline & $16001-21000$ & $\begin{array}{l}37 \\
(12.3)\end{array}$ & & \\
\hline & $>21000$ & $\begin{array}{l}40 \\
(13.3)\end{array}$ & --- & --- \\
\hline \multirow{3}{*}{ Type of Home } & Pakka & $\begin{array}{l}143 \\
(47.7)\end{array}$ & --- & --- \\
\hline & Kacha (Mud house) & $\begin{array}{l}58 \\
(19.3)\end{array}$ & & \\
\hline & Mix (Pakka, Kacha) & $\begin{array}{l}99 \\
(33.0) \\
\end{array}$ & --- & --- \\
\hline \multirow{3}{*}{ Occupation } & Self-employee & $\begin{array}{l}112 \\
(37.3)\end{array}$ & --- & --- \\
\hline & Laborer & $\begin{array}{l}95 \\
(31.7)\end{array}$ & & \\
\hline & Government & $24(8.0)$ & & \\
\hline
\end{tabular}




\begin{tabular}{|c|c|c|c|c|}
\hline & \multicolumn{4}{|l|}{ employee } \\
\hline & Private employee & $25(8.3)$ & & \\
\hline & Other & $\begin{array}{l}44 \\
(14.7) \\
\end{array}$ & --- & --- \\
\hline \multirow{3}{*}{ School Distance } & Half kilometer & $\begin{array}{l}97 \\
(32.3)\end{array}$ & --- & --- \\
\hline & One kilometer & $\begin{array}{l}92 \\
(30.7)\end{array}$ & & \\
\hline & Above one kilometer & $\begin{array}{l}111 \\
(37.0) \\
\end{array}$ & --- & --- \\
\hline \multirow{2}{*}{ Cultural } & \multirow{2}{*}{26} & & 38.8 & 5.4 \\
\hline & & 56 & 4 & 9 \\
\hline \multirow{2}{*}{ Parental } & \multirow{2}{*}{11} & & 20.9 & 3.8 \\
\hline & & 31 & 6 & 4 \\
\hline \multirow[t]{2}{*}{ School Facilities } & \multirow[t]{2}{*}{8} & & 17.8 & 3.4 \\
\hline & & 28 & 6 & 9 \\
\hline
\end{tabular}

Table number 1 shows that 155 (51.7) percent of the respondents were uneducated; 63 (21.0) percent of the respondents were primary; 41 (13.7) percent of the respondents had secondary and 41 (13.7) percent of the respondents had higher secondary. The results depicted that there was 85(23.3) percent of the respondents whose monthly income was $<6000 ; 62(20.7)$ percent of the respondent's monthly income was 6000-11000; 76 (25.3) percent of the respondent's monthly income was 16001-21000 and 40 (13.3) percent of the respondent's monthly income was $<21000$. The 143(47.7) percent of the respondents have Pakka homes; 58 (19.3) percent of the respondents had Kacha (Mud houses); 99 (33.0) percent of the respondents had mixed (Pakka, Kacha) houses. There were 112 (37.3) percent of the respondents who were self-employed; 95 (31.7) percent of the respondents were laborers; 24 (8.0) percent of the respondents were government employees; 25 (8.3) percent of the respondents were a private employee and 44 (14.7) percent of the respondents who were doing other works. There was 97 (32.3) percent of the respondents whose school and home distance was half a kilometer; 92 (30.7) percent of the respondents home and school distance was one kilometer 
and there was 111 (37.0) percent of the respondents whose school and home distance was above than one kilometer.

Table 2: Correlation between Cultural, Parental and School facilities

\begin{tabular}{llll}
\hline Variable & 1 & 2 & 3 \\
\hline Cultural & 1 & & \\
Parental & $.147^{*}$ & 1 & \\
School Facilities & $.585^{* *}$ & $.566^{* *}$ & 1 \\
\hline
\end{tabular}

Table 2 indicates the correlations between the study variables. The findings reveal that culture is significantly and positively correlated with parental and school facilities with p-values .011 and .000 respectively. Furthermore, parental is significantly and positively correlated with school facilities with a p-value .000 .

Table 3: ANOVA on the levels of cultural, parental and school facilities among different academic qualification of the household

ANOVA Table

\begin{tabular}{lllllll}
\hline Variable & $\begin{array}{l}\text { Source } \\
\text { variable }\end{array}$ & $\begin{array}{c}\text { of Sum of Df } \\
\text { Squares }\end{array}$ & $\begin{array}{l}\text { Mean } \\
\text { Square }\end{array}$ & F & Sig. \\
\hline \multirow{5}{*}{ Cultural } & $\begin{array}{l}\text { Between } \\
\text { Groups }\end{array}$ & 734.279 & 3 & 244.760 & 8.763 & .000 \\
& $\begin{array}{l}\text { Within } \\
\text { Groups }\end{array}$ & 8267.358 & 296 & 27.930 & & \\
& $\begin{array}{l}\text { Total } \\
\text { Between }\end{array}$ & 9001.637 & 299 & & & \\
& $\begin{array}{l}1512.914 \\
\text { Proups }\end{array}$ & 3 & 504.305 & 51.534 & .000 \\
& $\begin{array}{l}\text { Garental } \\
\text { Within }\end{array}$ & 2896.606 & 296 & 9.786 & & \\
& $\begin{array}{l}\text { Groups } \\
\text { Total } \\
\text { School }\end{array}$ & 4409.520 & 299 & & & \\
Facilities & $\begin{array}{l}\text { Getween } \\
\text { Groups }\end{array}$ & 796.609 & 3 & 265.536 & 27.661 & .000 \\
& $\begin{array}{l}\text { Within } \\
\text { Groups } \\
\text { Total }\end{array}$ & 2841.511 & 296 & 9.600 & & \\
\hline
\end{tabular}


Table number 3 depicted that the results of ANOVA on the levels of cultural, parental, and school facilities among different academic qualifications of the household. The findings show that there is a significant difference in the levels of cultural, parental and school facilities among different academic qualification of the household with p-values $.000, .000$ and .000 respectively.

Table 4: ANOVA on the Levels of Cultural, Parental and School Facilities among Different Monthly Income Levels

\begin{tabular}{|c|c|c|c|c|c|c|}
\hline Variable & $\begin{array}{l}\text { Source } \\
\text { variable }\end{array}$ & $\begin{array}{l}\text { Sum of } \\
\text { Squares }\end{array}$ & $\mathrm{df}$ & $\begin{array}{l}\text { Mean } \\
\text { Square }\end{array}$ & $\bar{F}$ & Sig. \\
\hline \multirow{3}{*}{ Cultural } & $\begin{array}{l}\text { Between } \\
\text { Groups }\end{array}$ & 2223.027 & 4 & 555.757 & 24.186 & .000 \\
\hline & $\begin{array}{l}\text { Within } \\
\text { Groups }\end{array}$ & 6778.610 & 295 & 22.978 & & \\
\hline & Total & 9001.637 & 299 & & & \\
\hline \multirow{3}{*}{ Parental } & $\begin{array}{l}\text { Between } \\
\text { Groups }\end{array}$ & 418.375 & 4 & 104.594 & 7.731 & .000 \\
\hline & $\begin{array}{l}\text { Within } \\
\text { Groups }\end{array}$ & 3991.145 & 295 & 13.529 & & \\
\hline & Total & 4409.520 & 299 & & & \\
\hline \multirow{3}{*}{$\begin{array}{l}\text { School } \\
\text { Facilities }\end{array}$} & Between & 597.077 & 4 & 149.269 & 14.480 & .000 \\
\hline & $\begin{array}{l}\text { Groups } \\
\text { Within } \\
\text { Groups }\end{array}$ & 3041.043 & 295 & 10.309 & & \\
\hline & Total & 3638.120 & 299 & & & \\
\hline
\end{tabular}

Table number 4 presented the results of ANOVA on the levels of cultural, parental, and school facilities among different monthly income levels of the household. The findings showed that there was a significant difference in the levels of cultural, parental and school facilities among different monthly income levels of the household with p-values $.000 ; .000$, and .000 respectively.

\section{Discussion}

The researcher asked different questions to the respondents to know the issues and challenges of girls' education in the studied area. It was found that majority 155 (51.7) percent of the 
respondents were uneducated. Different researches indicated that parent's education has a big role in the children education. The lower academic qualification of the parents led towards children exclusion from basic education.

The results indicated the poor economic status of the respond en ts. The previous studies showed that poor household was the one of the constraints of girl's education (Bass, 2004; Sattar et al., 2012). There were 112 (37.3) percent of the respondents who were self-employed; 111 (37.0) percent of the respondents whose school and home distance was above than one kilometer. The prior studies showed that longer distance of the school and home played a negative role in the education of the girls (Donnell, 2005; Gunnarsson, 2006; Wall, 2006; De Silva, 2008).

Table number 2 indicated the correlations between the study variables. The findings reveal that cultural is significantly and positively correlated with parental and school facilities with $\mathrm{p}$ values .011 and .000 respectively. Furthermore, parental is significantly and positively correlated with school facilities with $\mathrm{p}$ value .000 . It was mentioned by numerous studies that the patriarchal structure of the society negatively affected the girls' education (Herz and Sperling 2004; Chaudhry, 2007; Huisman \& Smits, 2009; Kurosaki et al., 2006; Mukherjee \& Das, 2008).

Table number 3 depicted that the results of ANOVA on the levels of cultural, parental and school facilities among different academic qualification of the household. The findings shows that there is significant difference in the levels of cultural, parental and school facilities among different academic qualification of the hous ehold with p-values $.000, .000$ and .000 respectively. The studies show that there is a close connection between cultural practices, parental attitude, and school facilities. The shortage of school facilities compelled the parents to send their children for earning or domestication instead of getting an education (Noshab, 2006; Latif, 2009).

Table number 4 presented the results of ANOVA on the levels of cultural, parental and school facilities among different monthly income levels of the household. The findings showed that there was a significant difference in the levels of cultural, parental and school facilities among different monthly income levels of the household with p-values $.000 ; .000$, and .000 respectively. It was 
found in the different studies that lower income hou seholds were probably not sent their children in the school as compare to those whose monthly income was modest and high (Ministry of Education, 2001; Farah, 2007; Colclough et al., 2003 and Chege \& Sifuna, 2006; UNESCO, 2010).

\section{Conclusion}

It can be concluded that girls of the studied areas were facing a lot of gendered, patriarchal, structural, school distance, cultural and many other issues regarding their education. The results showed that the lower socio-economic status; patriarchal structure, lack of school facilities led towards girls exclusion from the basic educational right. It is recommended that government may have to pay attention in the studied area; construct new schools, give scholarships to needy students and start awareness seminars at the local level. 


\section{References}

1. Aftab. T. (2004). "What Works and What Doesn't: A Ca se Study of Female Literacy in Pa kistan."Convergence27: 25-34

2. Alam, A. (2011). Impact of gender discrimination on gender development and poverty alleviation. Sarhad J. Agric, 27(2), 330-331.

3. Bacha Kahan Trust, (2009). "Poverty, Gender, and Primary School Enrolment in Pakistan" The Pa kistan Development Review 38 (4) PP: 979-992

4. Bass, L.E. (2004). Child la bor in sub-Saharan Africa. Lynne Rienner Publishers.

5. Bilquees, F., \& Saqib, N. (2004). Dropout rates and inter-school movements: Evidence from panel data in Pakistan. Islamabad: Pakistan Institute of Development Economics.

6. Bourdillon, M.F., Levison, D., White, B., \& Myers, W. (2010). Rights and wrongs of children's work. Rutgers university press.

7. Buchmann, C.(2000), "Family structure, parental perceptions, and child labor in Kenya: what factors determine who is enroll in school?", SocialForces, Vol. 78 No. 4, pp. 1349-1378.

8. Chaudhry, I. S. (2007). Gender inequality in education and economic growth: ca se study of Pakistan. Pakistan Horizon, 60(4), 81-91.

9. Chaudhry, I. S. (2009). Poverty alleviation in Southern Punjab (Pakistan): An empirical evidence from the project area of Asian Development Bank. International Research Journal of Finance and Economics, 23(23), 23-32.

10. Chrispell, J. H. and River, F. (2001). Engaging Latin Families for Studentsuccess: How parentEducation can reshape parents sen se of place in the education of their children. Peabody Journal of education 76(2) 119-169.

11. Dollar, D., \& Gatti, R.(1999). Gender inequality, income, and growth: are good times good for women? (Vol. 1). Washington, DC: Development Research Group, The World Bank.

12. Edmonds E., Pavenik N. (2005).Child labor in the global economy. Journal of Economic Perspectives, 18 (1),pp. 199-220

13. Farah, Iffat. 2007. Female Education in Pakistan: A Review. InGender and Education in Pakistan,eds. Rashida Qureshi and Jane F.A. Rarieya, 3-40. Karachi, Pakistan: Oxford University Press.

14. February 15, 2008 from http://www.moe.gov.pk/npadocs.htm.

15. Groot,(2007). "Gender Disparity in Education-Extents, Trends and Factors" Journal of Research (Faculty of Languages \& Islamic Studies)

16. Gunnarsson, V., Orazem, P., \& Sanchez, M. (2006). Child la bor and school a chievement in La tin America. World Bank Economic Review, $20,31-54$. 
17. Gunnarsson, V., Orazem, P., \& Sanchez, M. (2006). Child la bor and school a chievement in Latin America. World Bank Economic Review, 20,31-54.

18. Herz, Barbara Knapp, and Gene B. Sperling. 2004.What Works in Girl's Education: Evidence andPolicies from the Dev elo ping World. New York: Councilon Foreign Relations.

19. Hountenvilli, A. J.and Conway, S. (2008). Parental Involvement Strongly Impact Student Achievement .Science Daily. Pp 28, May $16^{\text {th }}$

20. Huisman, J., \& Smits, J. (2009). Effects of household-and district-level factors on primary school enrollment in 30 developing countries. World development, 37(1), 179-193.

21. Kafas, P. (2009). Child Neglect. A Review; The Internet Journal of ForensicScience.

22. Klasen, Stephan. (1997). Poverty, Inequality and Deprivation in South Africa: An Analysis of the 1993 Saldru Survey. Social indicators Research, 41, 51-94.

23. Klasen, Stephan. (1999). Does Gender In equality Reduce Growth and Development? World Bank Policy Research Report, Working Pa per Nr. 7. Washington, DC: The World Bank.

24. Kurosaki, T., Ito, S., Fuwa, N., Kubo, K., \& Sa wa da, Y.(2006). Child labor and school enrollment in rural India: Whose education matters? The Developing Economies, 44(4), 440-464.

25. Latif, A. (2009). A critical analysis of school enrollment a nd literacy ra tes of girls and women in Pa kistan. Educational Studies, 45(5), 424 439.

26. Latif, Amna. 2009. The socio-cultural context of curriculum and literacy: Lessons lea rned throughgirls' narratives in Pak istan. Pa per delivered at the annual conference of the American EducationalResearch Association, San Diego.

27. Malik, Shahnawaz. (1996). Determinants of RuralPoverty in Pakistan: A Micro Study. The Pakistan Development Review,35 (2), 171-187.

28. Ministry of Education. (2001). National Pla n of Action. Islamabad, Pakistan:, Government of Pakistan.

29. Mukherjee, D., \& Das, S. (2008). Role of parental education in schooling and child la bour decision: Urban India in the la st decade. SocialIndicators Research, 89(2), 305-322

30. Muslims, (2010). "Impact of Gender Inequality in Education on Economic Growth: An Empirical Evidence from Pakistan" The Pakistan Horizon Vol. 60, No.4

31. Nasir,Z.M. (2002). Returns to Human Capital in Pakistan: A Gender Disaggregated Analysis. The Pakistan Development Review, 41 (1), 1 28.

32. Noshab, Farzana. 2006. "Globalization, WTO, and Pakistan.”The Muslim World 96: 341-362.P' erez, Bertha, and T. L. McCarthy. 
2004. Sociocultural Contexts of Language and Literac y. Mahwah,NJ: LawrenceErlbaum Associates.

33. O'Donnell, O., Doorslaer, E., \& Rosati, F. (2005). Health effects of child work: Evidence from rural Vietnam. Journal of Population Economics, 18(3), 437-467.

34. Rao, N. S. (1991). Counseling and Guidance. New Delhi, McGraw_Hill

35. Shah, Dawood. 2003.Decentralization in the Education System of Pakistan: Policies and Strategies.Islamabad, Pakistan: Ac ademy of Educational Planning and Management, Ministry of Education, Government of Pakistan.

36. Starkey, P. and Kleir, A. (2000). Fostering Parental Support for Children's Mathematical Development: An intervention with Head sta rt Families Ea rly and Development. 11(5)659-680.

37. UNESCO Institute for Statistics (UIS). (2018). "One in Five Child ren, Adolescents and Youth is Out of School." UIS fact sheet No. 48. Montreal: UIS.

38. UNICEF. (2016). The state of the world's children 2016: a fair chance for every child.

39. Wall, (2006) "Are Educational Gender Gaps a Brake on Economic Development? Some Cross Country Empirical Evidence" Oxford Economic Papers, 54 (1). PP: 118-149.

40. World Bank.(2001). Poverty in Pakistan in the 1990's: An interim a ssessment report. Pakistan Human Development Forum, Islamabad.

41. Za far, (2007. "The Impact of Gender Inequality in Education and Employment on Economic Growth in Development Countries: Updates and Extensions" 